7. Костова Н. І. Прогалини вдосконалення цивільного законодавства. Наукові записки міжнародного гуманітарного університету. № 18. - 2013 p. - С. 66-69. [Електронний ресурс]. - Режим доступу: http://www.sci-notes.mgu.od.ua/archive/v18/26.pdf

8. Луць В. В. Договірне право України: сучасний стан і тенденції розвитку. Юридичний вісник. Повітряне і космічне право. - 2009. № 2. - С. 52-55. [Електронний ресурс]. - Режим доступу: http://nbuv.gov.ua/UJRN/Npnau_2009_2_12

9. Вишняков О. К. Апроксимація правового забезпечення цивільних майнових відносин в Україні до умов внутрішнього ринку Європейського Союзу: дис. д-ра юрид. наук / О. К. Вишняков. - Одеса, 2008. [Електронний ресурс]. - Режим доступу: http://dspace.onua.edu.ua/ handle/11300/8569

10. Стефанчук Р. О. Цивільне право України: навчальний посібник. К.: Прецедент, 2005. [Електронний ресурс]. - Режим доступу: http://www.ebk.net.ua/Book/law/stefanchuk_tsivpu/zmist.htm

DOI https://doi.org/10.30525/978-9934-588-92-1-37

\title{
КАМКОРДИНГ ЯК ПОРУШЕННЯ АВТОРСЬКИХ ПРАВ НА КІНЕМАТОГРАФІЧНИЙ ТВІР
}

\author{
Лубчук О. Д. \\ аспірантка кафедри інтелектуальної власності, \\ інформаційного та корпоративного права \\ Львівського національного університету імені Івана Франка \\ м. Львів, Україна
}

Камкординг - один 3 найбільш поширених видів піратства у кінематографічній сфері. В Україні на законодавчому рівні поняття камкордингу було закріплено після прийняття 23 березня 2017 року Закону України «Про державну підтримку кінематографії в Україні» [1]. Внаслідок прийняття наведеного Закону були внесені відповідні доповнення у Закон України «Про авторське право і суміжні права» [2]. Одним із таких доповнень стало визначення поняття камкордингу як відеозапису аудіовізуального твору під час його публічної демонстрації в кінотеатрах, інших кіновидовищних закладах особами, які перебувають у тому самому приміщенні, де відбувається така публічна 
демонстрація, для будь-яких цілей без дозволу суб'єкта авторського права або суміжних прав. До того ж було розширено зміст поняття піратства у сфері авторського права й суміжних прав, зокрема, шляхом включення камкордингу до переліку піратських дій.

Відповідні зміни було внесено й у ст. 176 Кримінального кодексу України [3], яка встановлює відповідальність за порушення авторського права і суміжних прав. Щоправда, закріплення камкордингу в якості одного із кримінально караних порушень не забезпечило остаточного вирішення проблеми несанкціонованого відеозапису кінематографічної продукції в Україні. До того ж на сьогодні явище камкордингу стало доволі поширеною проблемою Інтернет-середовища. Адже, як зазначає Ю.Ю. Симонян, найчастіше мета камкордингу полягає в подальшому поширенні такого запису в файлообмінних мережах Інтернету, що призводить не тільки до зменшення касових зборів в кінотеатрах, але й відображається на наступних продажах таких фільмів на DVD [4, с. 139].

Що ж стосується основних форм, в яких здійснюється піратська діяльність відносно кінофільмів та іншої аудіовізуальної продукції, то серед них виокремлюють дві ключові форми: нелегальне використання кабельних i супутникових передач та виготовлення копій на матеріальних носіях, як правило, у вигляді відеокасет. До того ж за піратського виготовлення відеокасет (аудіовізуальних творів) підпільне дублювання, як правило, здійснюється наступним чином: 1) з 35-міліметрової копії кінематографічного твору, тимчасово одержаної у розповсюджувача або в кінотеатрі кимось із осіб, близьких до прокатника. Така процедура використовується для комерціалізації кінематографічного твору у формі відеокасети, перш ніж ії випустить виробник або власник ліцензії, наданої виробником; 2) із законної копії iii запису, дубльованої на чистій касеті; 3) з телепередачі, записаної на чисту касету, яка потім дублюється [5, с. 71-72].

Основними ознаками контрафактності аудіовізуальних творів на DVD дисках $є$ : відсутність на поліграфічній упаковці даних про зону території розповсюдження i формат запису, відсутність або невідповідність коду IFPI, коду виробника і коду тиражу на диску, відсутність або невідповідність відомостей про виробника компактдиска, наявність на диску двох і більше фільмів, низька ціна в порівнянні із законно виданими примірниками [4, с. 139].

До того ж розповсюдження на території України примірників аудіовізуальних творів, а також їх прокат дозволяються лише за умови їх маркування контрольними марками [6]. Щоправда, хоч голографічне маркування сприяло легалізації ринку, існують тіньові схеми, за якими незаконно отримують контрольні марки, зокрема, 3 використанням 
фіктивних ліцензійних угод. Крім того, захисні елементи марки недосконалі, у зв'язку з чим порушникам вдається підробками маркувати контрафактну продукцію [4, с. 139].

На сьогодні в Україні діє некомерційна організація «Українська антипіратська асоціація». Серед основних завдань останньої варто відзначити сприяння правоохоронним та іншим державним органам у виявленні випадків порушення авторських прав, а також сприяння впровадженню та розповсюдженню технічних засобів боротьби 3 недозволеним або незаконним використанням об'єктів інтелектуальної власності, в тому числі з піратством у кінотеатрах [7]. Крім того, для попередження i виявлення камкордингу в Україні 32009 року діє Цільова програма по виявленню фактів камкордингу в кінотеатрах України, якою передбачено виплату грошової винагороди особі, яка безпосередньо виявила факт камкордингу в кінотеатрі, в сумі від 1000 гривень [4, с. 138].

В контексті дослідження основних шляхів запобігання камкордингу в Україні заслуговує на увагу також позитивний досвід іноземних держав у цій сфері. Йдеться насамперед про ті країни, в яких діє спеціальне законодавство щодо протидії камкордингу. Так, Конгресом Філіппін у 2010 році було прийнято спеціальний акт про заборону й покарання за неправомірне використання, зберігання та / або управління засобами аудіо- та відеофіксації для несанкціонованого запису кінематографічних фільмів й інших аудіовізуальних творів та / або їх саундтреків у місцях публічного показу [8]. Відповідно до цього Акту будь-яка особа, затримана у процесі використання або ж при спробі використання засобу аудіо- та відеофіксації для копіювання будь-якої частини кінематографічного фільму чи іншого аудіовізуального твору у місці публічного показу, повинна бути засуджена до позбавлення волі на термін від шести місяців і одного дня до шести років й одного дня, та штрафу від 1000 до 17000 доларів. До того ж судді повинні встановити максимальне покарання за такі дії, якщо метою камкордингу або ж спроби вчинити камкординг слугували продаж, прокат або ж інше комерційне розповсюдження копії.

Порівняння статистичних даних щодо вчинення камкордингу у перші три роки після прийняття вищерозглянутого закону засвідчило, що внаслідок запровадження останнього кількість несанкціонованих записів кінематографічної продукції в країні зменшилась на $95 \%$. В кінотеатрах були встановлені відкриті та приховані засоби протидії незаконній відеозйомці, системи охоронного відеоспостереження, почали застосовуватись окуляри нічного бачення тощо [9]. 
Враховуючи вищезазначене, зокрема, позитивний іноземний досвід у сфері протидії камкордингу, постає необхідність вдосконалення механізму протидії несанкціонованому відеозапису у кінематографічній сфері в Україні як шляхом посилення контролю за ринком кінопрокату, так і пошуку нових способів запобігання розповсюдженню контрафактних примірників кінематографічної продукції.

\section{Лiтература:}

1. Про державну підтримку кінематографії в Україні: Закон України від 23 березня 2017 р. // Відомості Верховної Ради України. 2017. № 20. Ст. 240.

2. Про авторське право і суміжні права: Закон України від 23 грудня 1993 року № 3792-XII // Відомості Верховної Ради України. 2001. № 43. Ст. 214.

3. Кримінальний кодекс України: закон України від 05.04.2001 № 2341-III // Відомості Верховної Ради Украӥни. 2001. № 25-26. Ст. 131.

4. Симонян Ю.Ю. Аудіовізуальні твори як об'єкти піратської діяльності // Часопис иивілістики. Наук. практ. журнал. 2012. № 14.

5. Доріс Лонг, Патриція Рей, Жаров В.О., Шевелева Т.М., Василенко I.Е., Дроб'язко В.С. Захист прав інтелектуальної власності: норми міжнародного і національного законодавства та їх правозастосування. Практичний посібник. К.: «К.І.С.». 2007.

6. Про розповсюдження примірників аудіовізуальних творів та фонограм, відеограм, комп'ютерних програм, баз даних: Закон України від 23 березня 2000 р. № 1587- III // Офіиійний вісник Украӥни. 2000. № 16. Стор. 11. Ст. 653.

7. Українська Антипіратська Асоціація. URL: https://apo.kiev.ua/

8. Anti - Camcording Act of 2010 (REPUBLIC ACT NO. 10088). URL: https://lawphil.net/statutes/repacts/ra2010/ra_10088_2010.html

9. Matikas Santos Anti-Camcording Law reduced film piracy in PH-group. URL: https://business.inquirer.net/69271/anti-camcording-lawreduced-film-piracy-in-ph-group 